\title{
夏季の温熱環境制御が睡眠と翌日の作業効率に与える影響の経済性評価 ECONOMIC EVALUATION ON THE EFFECT OF THERMAL ENVIRONMENTAL CONTROL IN SUMMER ON SLEEP AND WORK EFFICIENCY
}

\author{
本多英里 ${ }^{*}$, 伊香賀 俊治**, 大平 昇 ${ }^{* *}$, 岡島慶治 ${ }^{* * *}$, 海塩 涉 $* * * * *$ \\ Eri HONDA, Toshiharu IKAGA, Noboru OHIRA, \\ Keiii OKAIIMA and Wataru UMISHIO
}

\begin{abstract}
Reduced sleep quality is a serious problem. Previous studies have reported that the thermal environment affects sleep, and that although thermal environmental control via cooling is necessary, this increases energy consumption. Here, we conduct an economic evaluation of the impact of thermal environment control on both sleep quality and energy consumption through experiments conducted in August 2013 and 2014. Reduced sleep efficiency led to decreased work efficiency. The economic impact of improving sleep quality was much greater than that of energy consumption. This study showed importance of the improvement of the sleep quality.
\end{abstract}

Keywords : Thermal Environmental Control, Economic Evaluation, Sleep, Work Efficiency, Energy Consumption, Subject Experiment 温熱環境制御，経済性評価，睡眠，作業効率，エネルギー消費量，被験者実験

\section{1. 序論}

睡眠の質の低下は生活習慣病の罹患リスクを高め、更に睡眠障害 による日中の眠気が作業効率の低下や交通事故を引き起こすことが 明らかにされている ${ }^{1), 2)}$ 。厚生労働省が公表した平成 25 年国民健 康・栄養調查結果 ${ }^{3)}$ では、国民の約 2 割が睡眠に対して不満や悩み を抱えていることが明らかとなり、睡眠の質の低下は大きな社会問 題となっている。睡眠の質の低下を引き起こす要因の一つとしては、 温熱環境が睡眠中の体温調整と密接に関係していることから ${ }^{4)}$ 、夏 季の蒸し暑さが挙げられ ${ }^{5)}$ 、冷房を使用した適切な暑さ緩和対策が 求められている ${ }^{6)}$

このような背景を鑑みて、就寝中における温熱環境制御と睡眠の 関係が注目されてきた。垣鍔 7)-99 らは住宅内における夏期の冷房使 用に関する実測調查を実施し、冷房の使用実態を把握した上で、冷 房の使用方法が睡眠一与える影響の検証の必要性を示した。その後、 複数の泠房条件を設定した上で、8 組の男女を対象とした睡眠状態 の測定を実施し、冷房条件の好みを男女別に検証した。久保 ${ }^{10)} ら は$ 冷房の普及が進む一方で、冷房の不適切な使用が睡眠中の覚醒や起 床後の体調不良に影響を与えることを示唆し、睡眠中の適切な使用 方法を検証する重要性を示した。これを受け、川島 ${ }^{11)}$ らは、温度と 湿度を制御した計 3 ケースの条件下で、青年を対象とした被験者実 験を実施し、睡眠の質の向上に寄与する温熱環境制御の検討を行っ た。さらに、都築 ${ }^{12}$ ら $は$ 夏季に睡眠の質の低下が顕著である高齢者 を対象とした実験により、冷房の有無や冷房方式が睡眠時の皮膚温
や温冷感申告に影響寸ることを示した。また、系井川 ${ }^{13)}$ らは皮膚温 に加え、自律神経系の活動を考慮した対流式冷房の制御手法を提案 した。冷房の気流に着目したものとして、井上 ${ }^{14)}$ 、森戸 ${ }^{15)}$ らは冷風 が身体に直接当たらない制御手法が適していることを示した。以上 のように、冷房を使用した温熱環境制御が睡眠に与える影響に関す る研究が蓄積されつつある。

一方で、冷房を使用した温熱環境制御はエネルギー消費量の増加 を招く。我が国では、気候変動問題の深刻化に伴い、民生家庭部門 におけるエネルギー消費量の削減が喫緊の課題となっており 16)、そ の対策の 1 つとして、省エネ行動の実施が求められている。夏季に おいては、冷房の設定温度の上昇や使用時間の短縮等、温熱環境制 御に関する対策が居住者の省エネ行動実施率の上位を占めている 17)。しかし、冷房を全く使用しないといった過度な省エネ行動は睡 眠環境を悪化させ、睡眠障害の訴えを増加させる危険性が示唆され ている ${ }^{18), 19)}$ 。上述の研究では、温熱環境制御が睡眠に与える影響の みの検討にとどまっているため、省エネに与える影響までを含んだ 包括的な検討が求められている。

そこで本研究では、被験者実験を実施し、温熱環境制御が睡眠と エネルギー消費量に与える影響を総合的に検証する。両者の影響を 総合的に検証する手法としては既往研究 ${ }^{20)-24)}$ において多く用いら れている貨幣価值換算を用いる。貨幣価值の換算において、エネル ギー消費量の増加は冷房費の増加として推計可能である。一方、睡 眠効率の低下は翌日の作業効率の低下を引き起こし、人件費のロス

\footnotetext{
* 慶應義塾大学大学院理工学研究科 大学院生

** 慶應義塾大学理工学部 教授・博士 (工学)

*** 東京ガス(株) 博士 (工学)

**** 東京ガス侏

***** 鹿島建設株) 修士(工学)

(当時 慶應義塾大学大学院理工学研究科 大学院生)
}

Grad. Stud., Graduate School of Science and Technology, Keio Univ.

Prof., Faculty of Science and Technology, Keio Univ., Dr.Eng.

Manager, Residential Sales Marketing Department, Tokyo Gas Co., Dr.Eng.

Manager, Residential Sales Marketing Department, Tokyo Gas Co.

Kajima Corporation, M.Eng.

(Grad. Stud., Graduate School of Science and Technology, Keio Univ.) 


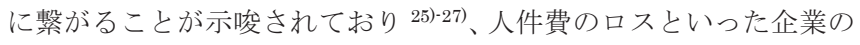
利益損失は労働者の賃金の減少に影響を与える ${ }^{28)}$ 。Goldsmith ${ }^{29)}$ ら の報告においても、作業効率及び作業意欲の低下が賃金の減少に繋 がることが示されている。そのため、本研究では睡眠効率の低下を 作業効率の低下が引き起こす賃金の減少と定義して推計を行う。し かし、睡眠効率と作業効率の関係に関しては定量的な検証が不十分 であるため、被験者実験を行い、睡眠状態の測定と翌日の作業効率 の測定を実施し、睡眠効率が作業効率に与える影響の定量化を行う。

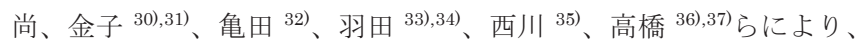
作業空間の室内環境が執務者の作業効率へ大きな影響を与えること が明らかにされている。そのため、実験期間中の作業空間の室内環 境を統一寸ることで、室内環境が作業効率へ与える影響を極力除去 するよう努めた。被験者実験により得られた睡眠効率、作業効率、 エネルギー消費量のデータを用いて、貨幣価值換算を行い、経済的 価値が高い室内温熱環境を検証する。

\section{2. 温熱環境制御と睡眠に関する被験者実験（2013 年）の概要 2.1 実験期間 - 被験者}

温熱環境制御が睡眠とエネルギー消費量に与える影響の検証を目 的とし、被験者実験を行った。実験は、神奈川県に所在する、断熱 水準が次世代省エネルギー基準を満たす集合住宅注 1)の 1 住戸にて 実施した。これ以降、「睡眠空間」と定義する。期間は、2013 年 8 月 2 5 日 ( $\mathrm{A}$ 日程)、8月 9 12 日 (B日程) の 2 回に分けて行っ た。被験者は、非喫煙者、かつ BMI 值注 2),38ににより標準的な体型と 判断された $20 \sim 22$ 歳の男子学生 8 名とした注 3$)$ 。また、飲酒習慣は 睡眠に大きく影響を及ぼす 39$)$ た、飲酒習慣が週に 1 回未満である 者を選定した。また、実験開始 1 2 週間前より極力規則正しい生 活を送るように指示し、睡眠状態の測定を実施した。被験者の普段 の総就床時間の平均は 6 時間 27 分であった注 4 。被験者は $\mathrm{A}, \mathrm{B}$ い ずれかの日程に参加し、各日程 4 名ずつとした。尚、正当な謝金を 支払うことを告知するとともに、事前説明会を実施した。個人情報 の取り扱い等に関して同意を得た上で、慶應義塾大学理工学部・理 工学研究科の生命倫理委員会の承認を得た手順で実験を実施した (承認番号 : 25-4)。

\section{2 実験ケース}

睡眠時の温熱環境制御ケースは、実生活における居住者の行動を 模擬し、冷房設定温度に関する全国アンケート結果の最頻値である $26^{\circ} \mathrm{C}$ 設定 (Case. I ) ${ }^{40)}$ 、省エネ推進のために政府が推奨している $28^{\circ} \mathrm{C}$ 設定（Case. II） ${ }^{41}$ 、冷房を使用しない自然通風（Case.III）の 計 3 ケースとした（表 1)。着衣は半袖と半ズボン（0.3clo）とし、 寝具は綿シーツをかけた敷布団とタオルケットに統一し、寝具の使 い方に関する制約は設けなかった注 5)。順序効果を極力除去するため、 $\mathrm{A}$ 日程と B 日程ではケースの順番を変えて実験を行った。ケース設 定と各日程の外気条件を表 2 に示す。

\section{3 実験スケジュール}

1 日の実験スケジュールを図 1 に示す。被験者は 19 時までに睡眠 空間に帰宅し、夕食を済ませた後、 21 時から 22 時の間に 1 人 15 分間を上限として入浴した。夕食に関しては、食事による睡眠への 影響を極力小さくするため、統一した夕食を用意した。入浴後から 心理量測定までは、激しい運動と仮眠を規制した上で過ごした。そ
表 1 睡眠時の温熱環境制御ケース（2013 年）

\begin{tabular}{l|c} 
Case. I & 冷房 $26^{\circ} \mathrm{C}$ 設定 $\quad$ (連続運転) \\
\hline Case. II & 冷房 $28^{\circ} \mathrm{C}$ 設定 $\quad$ (連続運転) \\
\hline Case. III & 自然通風 \\
\hline
\end{tabular}

表 22013 年実験日程と外気条件

\begin{tabular}{|c|c|c|c|c|c|c|c|c|}
\hline & \multicolumn{4}{|c|}{ A 日程 } & \multicolumn{4}{|c|}{ B 日程 } \\
\hline 実施日 & $8 / 2$ & $8 / 3$ & $8 / 4$ & $8 / 5$ & $8 / 9$ & $8 / 10$ & $8 / 1$ & $8 / 12$ \\
\hline Case & II & & & III & III & & II & I \\
\hline 天気 & 曇 & 晴一 & 時晴 & 量後晴 & $\begin{array}{c}\text { 薄量 } \\
\text { 時々晴 }\end{array}$ & & 晎 & 曇一時晴 \\
\hline 気温 $\left[{ }^{\circ} \mathrm{C}\right]$ & $23.7 \pm 0.3$ & & \pm 0.6 & $26.2 \pm 0.6$ & $28.1 \pm 0.8$ & & \pm 0.8 & $29.3 \pm 0.7$ \\
\hline 湿度[\%] & $79.1 \pm 1.0$ & & \pm 5.8 & $86.0 \pm 2.7$ & $84.8 \pm 3.2$ & & \pm 6.1 & $68.2 \pm 4.1$ \\
\hline
\end{tabular}

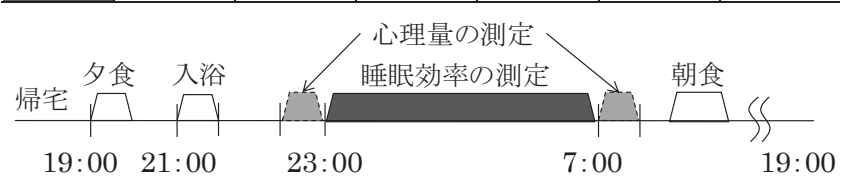

図 12013 年実験スケジュール
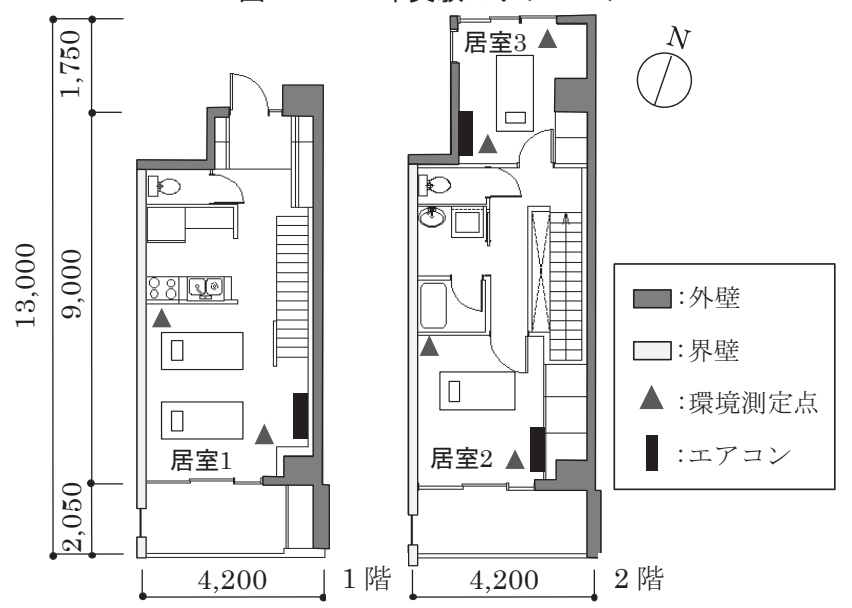

図 2 睡眠空間の平面図と物理環境測定点 (単位・mm) 表 3 睡眠空間の物理環境測定項目

\begin{tabular}{|c|c|c|c|}
\hline & 測定項目 & 測定機器 & 測定方法 \\
\hline 屋外 & 温度/湿度 & \multirow{2}{*}{$\begin{array}{c}\text { ワイヤレスデータロガー } \\
\text { (RTR-503) }\end{array}$} & \multirow{4}{*}{1 分間隔の } \\
\hline \multirow{6}{*}{ 室内 } & 温度/湿度 & & \\
\hline & グローブ温度 & グローブ球（080340-150) & \\
\hline & 風速 & クリモマスター風速（Model6533） & \\
\hline & 照度 & 照度計（T-10） & \multirow{3}{*}{$\begin{array}{c}\text { 就寝前 } \\
\text { 起床後に } \\
\text { 測定 }\end{array}$} \\
\hline & 騷音 & 普通騒音計（NL-21） & \\
\hline & $\mathrm{CO}_{2}$ 濃度 & IAQ モニター（Model2211） & \\
\hline
\end{tabular}

の後、23 時に消灯し、翌朝の 7 時まで睡眠状態の測定を行った。被 験者は実験者の合図によって起床した。総就床時間は統計局が実施 した社会生活基本調查において報告された 20〜24 歳男性の週全体 の平均総就床時間である 8 時間とし 注 6)、就寝前（消灯前）と起床後 に心理量、物理環境の測定を実施した。さらに、多機能ワイヤレス ホルタ記録器 CarPod（MEDILINK 社）を装着し、自律神経の 24 時間連続測定を行った注 7 。また、実験期間中の日中（9 時〜 19 時） は激しい運動、飲酒、昼寝等の規制を行った。

\section{4 測定項目}

(1)睡眠空間内の物理環境

実験を行った睡眠空間の平面図と物理環境測定点を図 2 に示寸。 環境測定点は被験者が睡眠をとった各部屋に 2 点ずつとした。測定

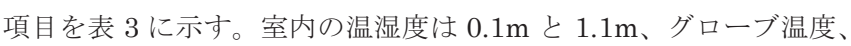


風速は $0.1 \mathrm{~m}$ の高さで 1 分間隔の連続測定を行った。照度、騒音、 $\mathrm{CO}_{2}$ 濃度は $0.1 \mathrm{~m}$ の高さで就寝前と起床後に測定した。また屋外の 温湿度についても、 $1.1 \mathrm{~m}$ の高さで 1 分間隔の連続測定を行った。

(2)エネルギー消費量

睡眠空間の各部屋に設置されているエアコンのエネルギー消費量 は 1 分間隔で積算值を測定した。エアコンは成績係数 (COP： Coefficient of Performance）が 3.23〜4.49 の省エネ型であった。

(3)睡眠状態

睡眠状態は、枕元に非接触型の睡眠計 HSL-102-M (OMRON 社) を設置し測定した。本実験で用いた睡眠計は、電波センサにより測 定した被験者の体動から睡眠・覚醒の状態を判定し、睡眠の質を評 価するものである。睡眠の指標としては、睡眠の質を判定する総合 的な指標として広く用いられ ${ }^{42}$ 、翌日の作業効率との関連が強い注 8)、総就床時間中の総睡眠時間の割合を示す睡眠効率を採用した。

\section{(4)心理量}

室内環境満足度や疲労感、睡眠感に関してアンケート調査を実施 した（表 4）。室内環境満足度は、就寝前と起床後に温熱、光、音、 空気質環境について 4 段階の評価を行った。体調、疲労感は就寝前 に調査した。体調は 4 段階の評価を行い、疲労感は自覚症状調べ 43$)$ を用いて頭痛、だるさといった 32 症状を問うた。睡眠感は、起床 後に OSA 睡眠調查票 MA 版注 9), 44)を用いて調查した。

\section{3. 睡眠と作業効率に関する被験者実験（2014 年）の概要 \\ 3.1 実験期間 · 被験者}

睡眠の影響を貨幣価值に換算する際に用いる指標となる睡眠効率 と作業効率の関係の定量化を目的として、被験者実験を行った。実 験は温熱環境制御と睡眠に関する実験場所と同様の集合住宅内の 1 住戸を「睡眠空間」、集会室を「作業空間」として実施した。期間は、 2014 年 8 月 $4 \sim 8$ 日 (A 日程)、 8 月 11 15 日（B 日程）の 2 回に 分けて行った。被験者は、非喫煙者、かつ BMI 值により標準的な 体型と判断された 20〜24 歳の男子学生 8 名とした注 3$), 10)$ 。また、飲 酒習慣が週に 1 回未満である者を選定した。被験者は $\mathrm{A}, \mathrm{B}$ いずれ かの日程に参加し、各日程 4 名ずつとした。尚、温熱環境制御と睡 眠に関する実験と同様に、正当な謝金を支払うことを告知するとと もに、事前説明会を実施した。個人情報の取り扱い等に関して同意 を得た上で、慶應義塾大学理工学部・理工学研究科の生命倫理委員 会の承認を得た手順で実験を実施した（承認番号：26-4)。

\section{2 実験スケジュール}

1 日の実験スケジュールを図 3 に示す。夜 19 時〜翌日 9 時まで の睡眠空間内の測定は 2.4 節に記載した温熱環境制御と睡眠に関す る実験と同様の内容である。睡眠時の温熱環境制御ケースは冷房の 設定温度を $26^{\circ} \mathrm{C}$ と $28^{\circ} \mathrm{C}$ 、運転方式を連続運転とタイマー使用 3 時 間 45) とする計 4 ケースとした（表 5)。翌日は 9 時までに作業空間 に移動した後、作業空間に慣らし作業前の状態を統一寸るため、15 分間椅座位安静状態とした。その後、9 時半から 90 分間の作業効率 の測定を実施した。作業効率測定時のスケジュールを図 4 に示す。 2 種類の模擬作業を 15 分毎に交互に実施し、作業効率の測定前後と 作業の切り替えのタイミングで心理量の測定を行った。また、実験 期間中の日中（11 時半〜19 時）は激しい運動、飲酒、昼寝等の規 制を行った。
表 4 心理量の測定項目

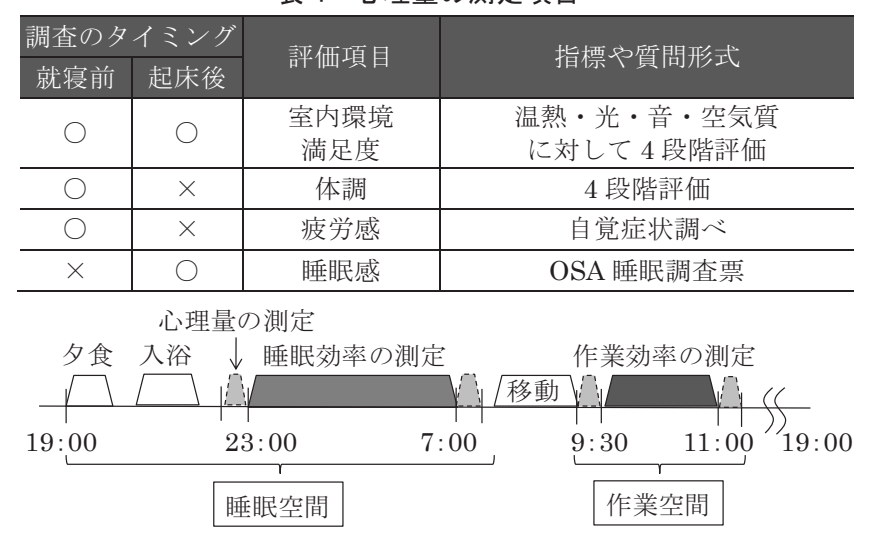

図 32014 年実験スケジュール

表 5 睡眠時の温熱環境制御ケース（2014 年）

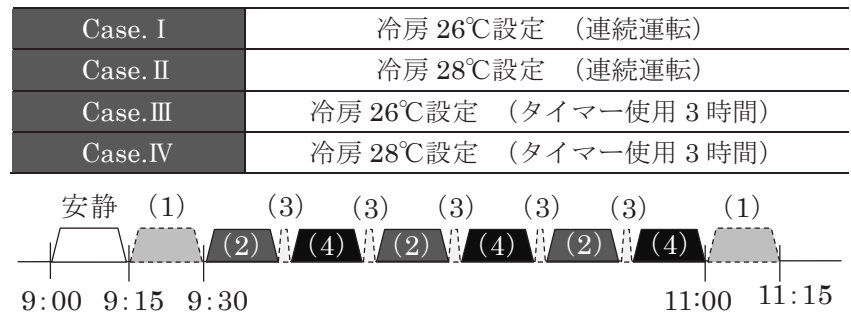

（1）：心理量の測定（作業前後）（2）：作業〔タイピング〕

（3）：心理量の測定（作業中）（4）：作業〔マインドマップ〕

図 4 作業効率測定時のスケジュール

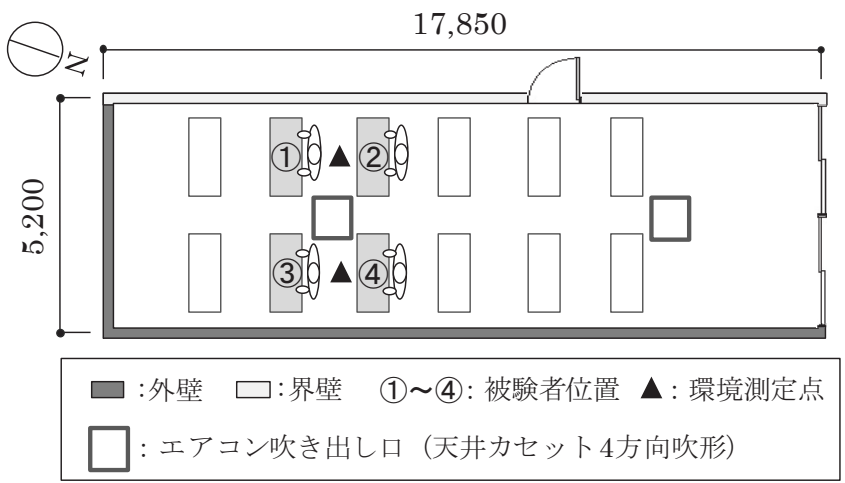

図 5 作業空間の平面図と物理環境測定点（単位・mm）

表 6 作業空間の物理環境測定項目

\begin{tabular}{|c|c|c|c|}
\hline & 測定項目 & 測定機器 & 測定方法 \\
\hline 屋外 & 温度/湿度 & \multirow{2}{*}{$\begin{array}{c}\text { ワイヤレスデータロガー } \\
\text { (RTR-503) }\end{array}$} & \multirow{4}{*}{$\begin{array}{c}1 \text { 分間隔の } \\
\text { 連続測定 }\end{array}$} \\
\hline \multirow{6}{*}{ 室内 } & 温度/湿度 & & \\
\hline & グローブ温度 & グローブ球（080340-150） & \\
\hline & 風速 & $\begin{array}{c}\text { クリモマスター風速計 } \\
\text { (Model6533) }\end{array}$ & \\
\hline & 照度 & 照度計（T-10） & \multirow{3}{*}{$\begin{array}{c}\text { 作業中 } \\
30 \text { 分間隔で } \\
\text { 測定 }\end{array}$} \\
\hline & 騒音 & 普通騒音計（NL-21） & \\
\hline & $\mathrm{CO}_{2}$ 濃度 & IAQ モニター (Model2211) & \\
\hline
\end{tabular}

\section{3 測定項目}

(1)作業空間内の物理環境

作業空間の平面図と物理環境測定点を図 5 示す。環境測定点は被 験者が作業を行った座席の中心に 2 点設けた。また、測定項目を表 6 に示す。室内の温湿度は $0.1 \mathrm{~m}, 0.6 \mathrm{~m}, 1.1 \mathrm{~m}$ の高さで、グローブ温 度と風速は $1.1 \mathrm{~m}$ の高さで 1 分間隔の連続測定を行った。照度、騒 
音、 $\mathrm{CO}_{2}$ 濃度は $1.1 \mathrm{~m}$ の高さで作業効率の測定中 30 分間隔で 1 日に 4 回測定した。また屋外の温湿度についても、 $1.1 \mathrm{~m}$ の高さで 1 分間 隔の連続測定を行った。

(2)作業効率

模擬作業の内容としては単純作業としてタイピング、知識創造作 業としてマインドマップ注 11)を採用し、各々の作業効率を測定した。 タイピングの作業効率は正答率により評価し、マインドマップは回 答数により評価を行った。尚、習熟の影響を極力除外するため、被 験者は事前に模擬作業の練習を行った。

(3)心理量

心理量の測定項目を表 7 に示す。室内環境満足度と体調・眠気は 作業前後に調査した。室内環境満足度は温熱、光、音、空気質環境 について 4 段階の評価を行った。眠気の評価には主観的な眠気を 9 段階で評価するカロリンスカ眠気尺度（KSS）を使用した。また、 作業の切り替え時には主観的な作業効率や作業意欲に関して、最も 作業が捗った時及び作業に対する意欲がある状態を $100 \%$ とた際 の相対評価を問うた。

\section{4. 温熱環境制御と睡眠に関する被験者実験の結果}

\section{1 睡眠空間における物理環境の測定結果}

寝室の環境要素の中で睡眠に影響を及ぼすとされる温熱、光、音

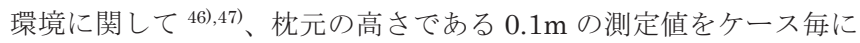
平均した結果を表 8 に示寸注 ${ }^{12)}$ 。光、音環境に関してケース間に有 意差は認められず、光、音環境の影響が小さいことを確認した。従 って、温熱環境が睡眠に与える影響の検証が可能であると考えられ る。夏季における体感温度は室温に加えて湿度が大きな影響を与え る。そのため、温熱環境の指標には温湿度、風速、放射の影響を考 慮した体感温度である標準新有効温度 $(\mathrm{SET}$ ） を用いて評価を行 った ${ }^{48)-52)}$ 。温湿度、風速、放射温度は実測值を採用した。また、標 準状態の人が睡眠空間にいた場合の体感温度を示すことで、温熱環 境制御によって形成される室内温熱環境を理解し易くするため、着 衣量及び代謝量は標準状態における $0.6 \mathrm{clo} 、 58.2 \mathrm{~W} / \mathrm{m}^{253)}$ とした注 ${ }^{13)}$ 。 就寝中 ( 23 時〜 7 時) の平均 $\mathrm{SET}^{*}{ }^{*}{ }^{\text {注 }}{ }^{14}$ は、 Case I では $24.9^{\circ} \mathrm{C} 、$ Case.

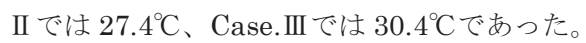

\section{2 エネルギー消費量の測定結果}

就寝中の冷房使用によるエネルギー消費量 (23 時〜 7 時の 8 時間 の積算值）をケース毎に示す (図 6)。Case. I では 0.06kWh/日 $/ \mathrm{m}^{2}$ 、 Case. II では $0.03 \mathrm{kWh} /$ 日 $/ \mathrm{m}^{2}$ となり、本実験において、冷房の設定 温度を $26^{\circ} \mathrm{C}$ から $28^{\circ} \mathrm{C} へ 2{ }^{\circ} \mathrm{C}$ 上昇させることによるエネルギー消費 量削減効果は $0.03 \mathrm{kWh} /$ 日 $/ \mathrm{m}^{2}$ ( $50 \%$ 削減) となった $(\mathrm{p}<0.01)$ 。羽 原 ${ }^{54)}$ らの調查では、冷房の設定温度を $26^{\circ} \mathrm{C}$ から $28^{\circ} \mathrm{C}$ に上昇させる ことよって、1日のエネルギー消費量が 63～65\%削減されると示し ている。本研究では夜間における冷房使用のみを分析対象としたた め、削減率がやや小さくなったものと推察される。

\section{3 室内温熱環境が睡眠感と睡眠効率へ与える影響}

室内温熱環境が睡眠の質に与える影響の検証を実施する。ここで、 就寝前のアンケート調査で体調が「悪い」と回答した 1 名は温熱環 境以外の要因が睡眠に及ぼす影響が大きいと考えられるため、分析 から除外した。また、分析対象とする 7 名に関して、実験期間中の 就寝前の疲労感が同等であることを確認した注 15 )。先ず、OSA 睡眠
表 7 作業効率測定時の心理量測定項目

\begin{tabular}{|c|c|c|c|c|}
\hline \multirow{2}{*}{ 評価項目 } & \multirow{2}{*}{ 指標や質問形式 } & \multicolumn{3}{|c|}{ 調查のタイミング } \\
\hline & & 作業前 & 作業後 & 作業中 \\
\hline $\begin{array}{l}\text { 室内環境 } \\
\text { 満足度 }\end{array}$ & $\begin{array}{l}\text { 温熱・光・音・空気質 } \\
\text { に対して } 4 \text { 段階評価 }\end{array}$ & 0 & 0 & $x$ \\
\hline 体調 & 4 段階評価 & 0 & 0 & $\times$ \\
\hline 眠気 & KSS（9段階評価） & 0 & 0 & $\times$ \\
\hline 作業意欲 & $0 \sim 100 \%$ 新伍 & $x$ & 0 & $\bigcirc$ \\
\hline 作業効率 & $0 \sim 100 \%$ 烊牦 & $x$ & $\bigcirc$ & O \\
\hline
\end{tabular}

表 8 睡眠空間内の物理環境測定結果（平均値士標準偏差）

\begin{tabular}{|c|c|c|c|c|}
\hline & Case. I & Case. II & Case.III \\
\hline \multicolumn{2}{|c|}{ 就寝中の室温 $\left[{ }^{\circ} \mathrm{C}\right]$} & $24.9 \pm 0.5$ & $26.7 \pm 0.7$ & $28.3 \pm 1.0$ \\
\hline \multicolumn{2}{|c|}{ 就寝中の湿度 [\%] } & $71.6 \pm 4.1$ & $74.9 \pm 2.5$ & $78.2 \pm 1.0$ \\
\hline \multicolumn{2}{|c|}{ 就寝中の $\mathrm{SET}^{*}\left[{ }^{\circ} \mathrm{C}\right]$} & $24.9 \pm 0.9$ & $27.4 \pm 1.4$ & $30.4 \pm 1.4$ \\
\hline \multirow{2}{*}{ 照度 [lx] } & 就寝前 & $130 \pm 68$ & $136 \pm 55$ & $140 \pm 66$ \\
\hline & 起床後 & $249 \pm 75$ & $222 \pm 97$ & $250 \pm 87$ \\
\hline \multirow{2}{*}{ 騒音 [dB] } & 就寝前 & $37.9 \pm 2.1$ & $37.5 \pm 1.5$ & $39.5 \pm 1.2$ \\
\hline & 起床後 & $37.6 \pm 1.8$ & $37.4 \pm 1.3$ & $39.7 \pm 1.3$ \\
\hline
\end{tabular}
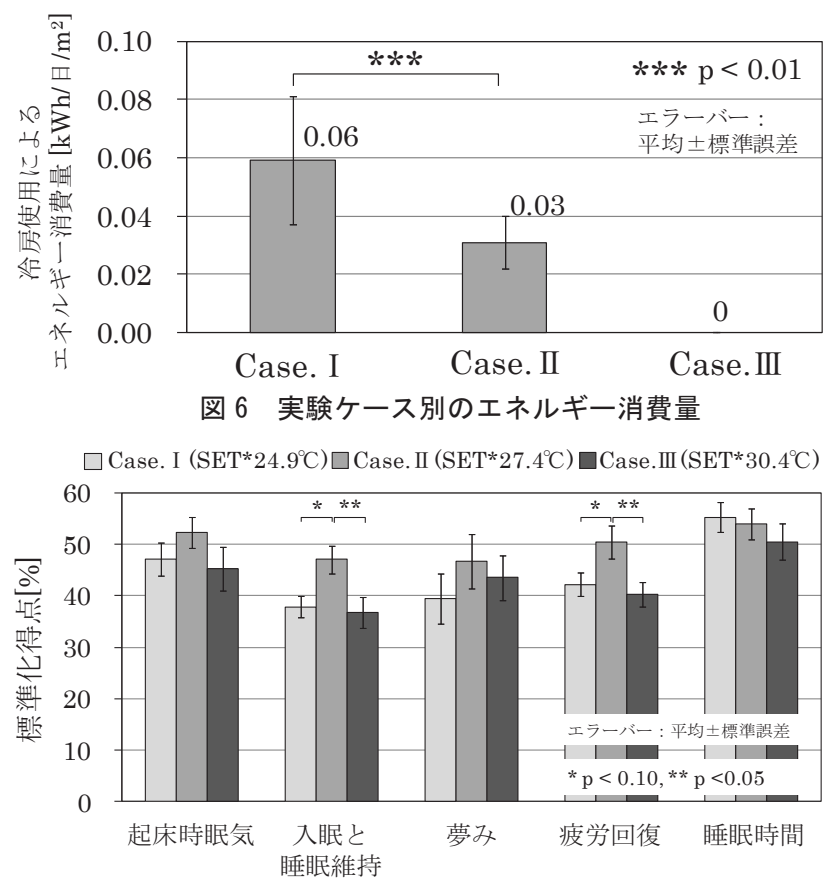

図 7 実験ヶース別の起床時の睡眠感 $(n=7)$

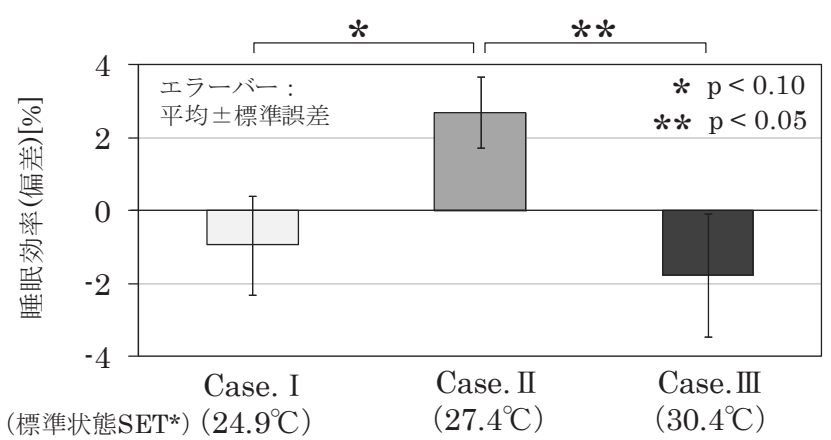

図 8 実験ケース別の睡眠効率 $(n=7)$

調查票 MA 版を用いて評価した、起床時の睡眠感注 16)をケース別に 示す（図 7)。「入眠と睡眠維持」及び「疲労回復」の項目において、 Case. II の得点が高い傾向が示唆された。次に、各ケースの就寝中 の平均 SET*と睡眠効率を図 8 に示す。ここで、睡眠効率は個人差 
が非常に大きいことから衤 17),18)、平均的に睡眠効率が高い人に対し ても、平均的に睡眠効率が低い人に対しても温熱環境制御ケースの 違いによる睡眠効率の変化量を等しく検討するため、偏差（被験者 の日ごとの睡眠効率一実験期間中の被験者の睡眠効率の平均值）を 用いて分析を行った。その結果、平均 $\mathrm{SET}^{*}$ が $27.4^{\circ} \mathrm{C}$ となった Case. II において睡眠効率が最も高くなる傾向が確認された。Case. II と Case. III を比較すると Case. III において睡眠効率が低下しており

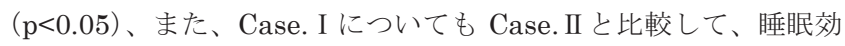
率が低下寸る傾向が得られた（ $<<0.10 ）$ 。ひより、過度な冷房使 用による低い SET*（Case. I ）と冷房を使用しないことによる高い SET* (Case.III) は、共に睡眠へ悪影響を及ぼし、睡眠に適切な SET* が存在することが示唆された。

\section{5. 睡眠と作業効率に関する被験者実験の結果 \\ 5.1 作業空間における物理環境の測定結果}

睡眠効率の低下による経済的影響を貨幣価值換算するため、睡眠 効率と作業効率の関係の定量化を行う。前述の通り、作業空間の室 内環境は執務者の作業効率へ大きな影響を与えることが明らかにさ

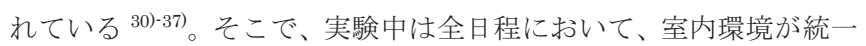
されるように冷房を $26^{\circ} \mathrm{C}$ 設定の連続運転とした。冷房の設定温度は、 既往研究 ${ }^{23}$ において、作業効率は室温 $25.7^{\circ} \mathrm{C}$ で最大となることが報 告されているため、予備実測により、冷房の設定温度と作業空間の 室温の関係を確認した上で、 $26^{\circ} \mathrm{C}$ 設定とした。作業空間内の物理環 境の測定結果を表 9 に示す。その結果、温熱環境・空気質環境・光 環境において「建築物における衛生的環境の確保に関する法律」の 定める室内環境基準を満たしており、音環境に関しても作業を行う 上で支障をきたすことのない状態であることを確認した ${ }^{55)}$ 。次に、 被験者の作業前後における室内環境満足度の調査結果を図 9 に示寸。 音、光、空気質環境に対しては全ての被験者が満足していることが 確認された。一方で、温熱環境に対しては作業前又は作業後に不満 を抱いている被験者が確認された。作業前又は作業後に温熱環境に 不満を抱いている被験者は作業空間内の温熱環境が作業効率に影響 を与えている可能性があるため、以降の分析から除外した。

\section{2 睡眠効率が眠気・作業意欲に与える影響}

睡眠効率と作業効率の関係を検証する前段として、睡眠効率が作 業前の眠気や作業中の作業意欲に与える影響を検証した。先ず、睡 眠効率とカロリンスカ眠気尺度を用いて調查した作業前の眠気の関 係を図 10 に示す。その結果、睡眠効率が低い日ほど、作業前に眠 気を感じている状態であることが確認された $\left(R^{2}=0.39, p<0.01\right)$ 。 次に、睡眠効率の偏差が 0 未満の群（睡眠効率が低い群）と睡眠効 率の偏差が 0 以上の群（睡眠効率が高い群）に分類し、作業中の作 業意欲を比較した (図 11)。睡眠効率の偏差が 0 以上の群において、 作業意欲が高く維持される傾向が示唆され、作業開始 90 分後の時 点では有意な差が認められた $(\mathrm{p}<0.05)$ 。

\section{3 睡眠効率が作業効率に与える影響}

睡眠効率が作業効率に与える影響を検証する注 19)。尚、作業効率 に関しても睡眠効率と同様に、個人差が大きい指標であるため、偏 差（被験者の日ごとの作業効率一実験期間中の被験者の作業効率の 平均值）を用い、個人差を極力除外した上で分析を行った。先ず、 睡眠効率と知識創造作業であるマインドマップの回答数との関係を
表 9 作業空間内の物理環境測定結果 (平均値土標準偏差)

\begin{tabular}{c|c|c|c|c|c|c} 
& $\begin{array}{c}\text { 室温 } \\
{\left[{ }^{\circ} \mathrm{C}\right]}\end{array}$ & $\begin{array}{c}\text { 湿度 } \\
{[\%]}\end{array}$ & $\begin{array}{c}\text { 気流 } \\
{[\mathrm{m} / \mathrm{s}]}\end{array}$ & $\begin{array}{c}\mathrm{CO}_{2} \text { 濃度 } \\
{[\mathrm{ppm}]}\end{array}$ & $\begin{array}{c}\text { 机上面 } \\
\text { 照度 }[\mathrm{lx}]\end{array}$ & $\begin{array}{c}\text { 騷音 } \\
{[\mathrm{dB}]}\end{array}$ \\
\hline $8 / 5$ & $25.1 \pm 0.3$ & $66.3 \pm 2.0$ & $0.14 \pm 0.03$ & $685 \pm 16$ & $756 \pm 7.4$ & $40.6 \pm 0.3$ \\
\hline $8 / 6$ & $25.3 \pm 0.3$ & $63.0 \pm 2.4$ & $0.11 \pm 0.03$ & $613 \pm 17$ & $742 \pm 5.5$ & $41.5 \pm 1.2$ \\
\hline $8 / 7$ & $25.2 \pm 0.5$ & $62.8 \pm 2.7$ & $0.09 \pm 0.04$ & $623 \pm 14$ & $754 \pm 13$ & $38.9 \pm 0.8$ \\
\hline $8 / 1$ & $25.4 \pm 0.5$ & $65.9 \pm 3.5$ & $0.12 \pm 0.03$ & $618 \pm 22$ & $751 \pm 6.9$ & $40.3 \pm 0.5$ \\
\hline $8 / 13$ & $25.2 \pm 0.3$ & $66.9 \pm 1.7$ & $0.12 \pm 0.03$ & $623 \pm 40$ & $760 \pm 13$ & $40.4 \pm 1.0$ \\
\hline $8 / 14$ & $25.2 \pm 0.3$ & $66.3 \pm 1.9$ & $0.11 \pm 0.03$ & $686 \pm 28$ & $762 \pm 9.1$ & $39.5 \pm 0.8$ \\
\hline $8 / 15$ & $25.3 \pm 0.3$ & $64.2 \pm 1.8$ & $0.12 \pm 0.03$ & $613 \pm 35$ & $755 \pm 8.9$ & $38.7 \pm 0.5$ \\
\hline
\end{tabular}

\begin{tabular}{|c|c|c|c|c|c|}
\hline 作業前 & \multicolumn{5}{|c|}{ 口非常に満足 口やや満足 口やや不満 } \\
\hline \multirow{4}{*}{$\begin{array}{r}\text { 温熱環境 } \\
\text { 音環境 } \\
\text { 光環境 } \\
\text { 空気質環境 }\end{array}$} & 11 & & 18 & & 3 \\
\hline & \multicolumn{3}{|c|}{23} & \multicolumn{2}{|c|}{9} \\
\hline & \multicolumn{3}{|c|}{23} & \multicolumn{2}{|c|}{9} \\
\hline & \multicolumn{3}{|c|}{22} & \multicolumn{2}{|c|}{10} \\
\hline & 20 & 40 & 60 & 80 & $\begin{array}{l}100 \\
{[\%}\end{array}$ \\
\hline
\end{tabular}

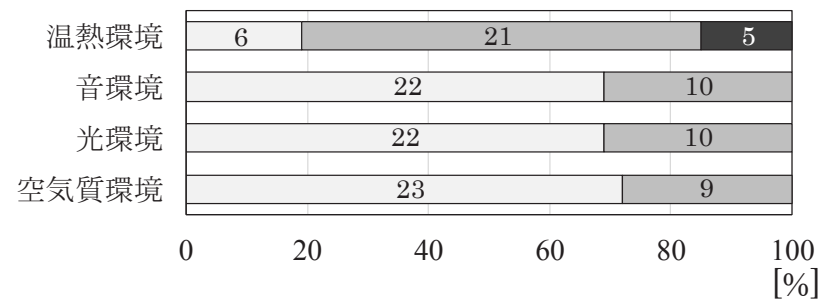

図 9 作業前後の室内環境満足度 $(n=32)$

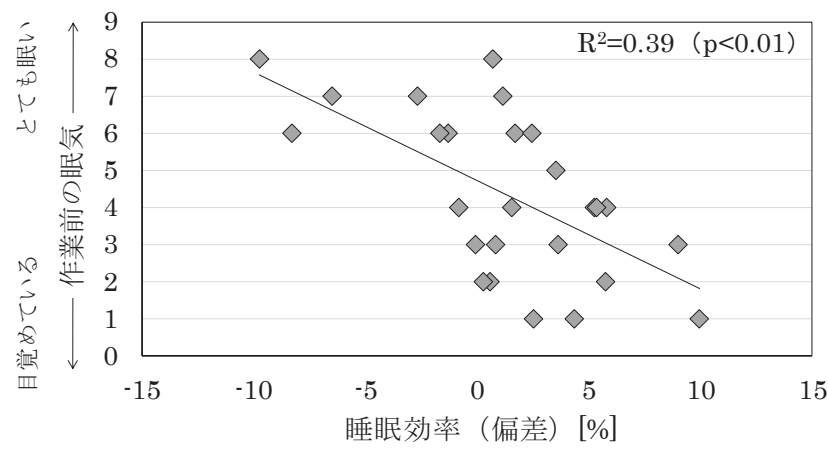

図 10 睡眠効率と作業前の眠気の関係 $(n=26)$

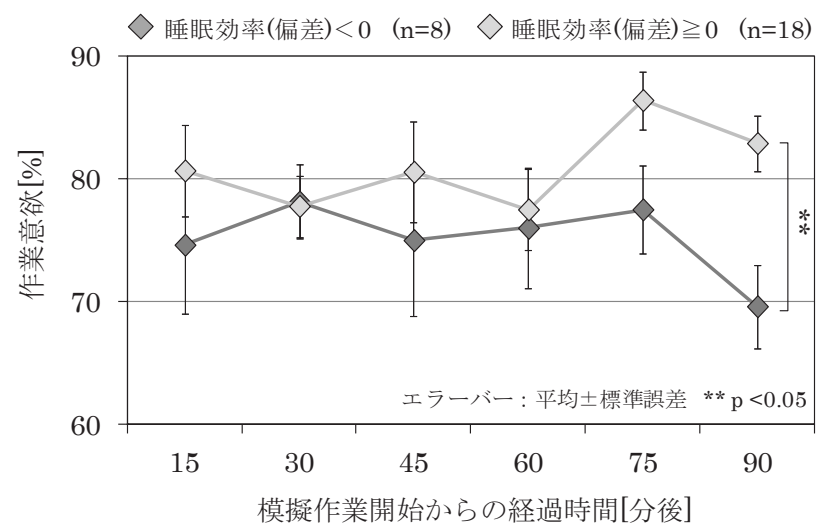

図 11 睡眠効率と作業意欲の関係 $(n=26)$ 
図 12 に示寸。睡眠効率が高い日ほどマインドマップの回答数が多 い傾向が確認された $\left(\mathrm{R}^{2}=0.26, \mathrm{p}<0.01\right)$ 。次に、睡眠効率と単純作 業であるタイピングの正答率との関係を示寸（図 13）。その結果、 睡眠効率が高い日ほどタイピングの正答率が向上する傾向が得られ、 睡眠効率 $1 \%$ の低下に伴い、作業効率が $1.1 \%$ 低下寸ることが示唆さ れた $\left(\mathrm{R}^{2}=0.67, \mathrm{p}<0.01\right)$ 。単純作業・知識創造作業ともに睡眠の質 の向上が好影響を与える可能性が明らかとなった。

\section{6. 温熱環境制御が睡眠と省エネに与える影響の経済性評価}

\section{1 睡眠効率の変化による経済的な影響}

5.3 節の結果より、睡眠効率の低下は翌日の作業効率の低下に影 響することが確認された。従って、睡眠効率の低下は作業効率の低 下を引き起こし、賃金の減少に繋がると推察される。睡眠効率の変 化による経済的影響を（1）式より算出した。

睡眠効率の変化による経済的影響[円/人/日 ]

$=$ 賃金 $[$ 円 $/$ 人/日 $] \times$ 睡眠効率（偏差）[\%]

$\times$ 睡眠効率 $1 \%$ の低下に伴う作業効率の変化率 $[\%] \cdot \cdots(1)$

賃金は、労働経済白書 ${ }^{56}$ による 2013 年の現金給与額（月額）で ある 31 万 4048 円、並びに 2013 年の月間労働時間 145.5 時間を用 い労働基準法で定められた 1 日当たりの法定基準時間である 8 時 間分の賃金を算出し、採用した。また、作業効率の低下率に関して は、オフィスで一般的に行われている作業 ${ }^{57)}$ であるタイピングの結 果を採用とし、図 13 から得られた睡眠効率 1\%低下に伴う作業効率 の変化率であるー $1.1 \%$ 用いた。

\section{2 エネルギー消費量の変化による経済的な影響}

冷房使用に伴うエネルギー消費量の増加、及びその経済的影響は 冷房費の増加として換算することが可能である。そこで、エネルギ 一消費量の変化による経済的影響を（2）式より算出した。

エネルギー消費量の変化による経済的影響[円/人/日]

$=(-1) \times$ エネルギー消費量 $\left[\mathrm{kWh} /\right.$ 日 $\left./ \mathrm{m}^{2}\right]$

$\times$ 夏季の家庭用エネルギー価格 $[$ 円 $/ \mathrm{kWh}]$

$\times$ 冷房面積 $\left[\mathrm{m}^{2}\right] \div$ 世帯人数 $[$ 人]

エネルギー消費量に関しては、冷房費の増加を居住者にとっての 負の経済的影響とするため、一 1 を乗じた。また、家庭用エネルギ 一価格には公益社団法人 全国過程電気製品公正取引協議会が定め る家庭用電力価格の 27 円 $/ \mathrm{kWh}^{58)}$ 用い、冷房面積には被験者が睡 眠をとった部屋の合計面積である $55.68 \mathrm{~m}^{2}$ を、世帯人数には各日程 の被験者数 4 名を用いた。

\section{3 睡眠効率及びエネルギー消費量の変化による経済的影響}

図 6、図 8 に示した実験ケース別の睡眠効率およびエネルギー消 費量を貨幣価值に換算した結果、さらに両者の影響を統合した結果 を図 14 に示す。その結果、睡眠の質向上がもたらす経済的影響は 省エネによる影響よりもはるかに大きいことが明らかとなった。本 実験におけるケース間比較において、最も経済的に価値の高い環境 は Case. II であることが示唆された。

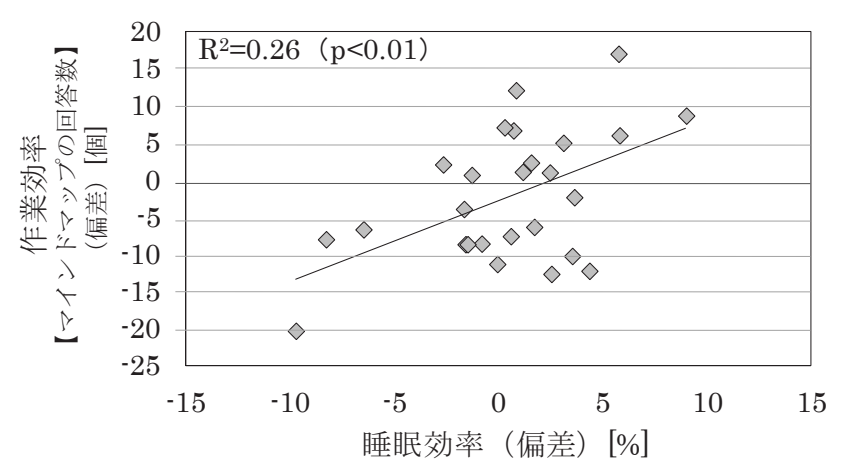

図 12 睡眠効率とマインドマップの回答数の関係 $(n=26)$

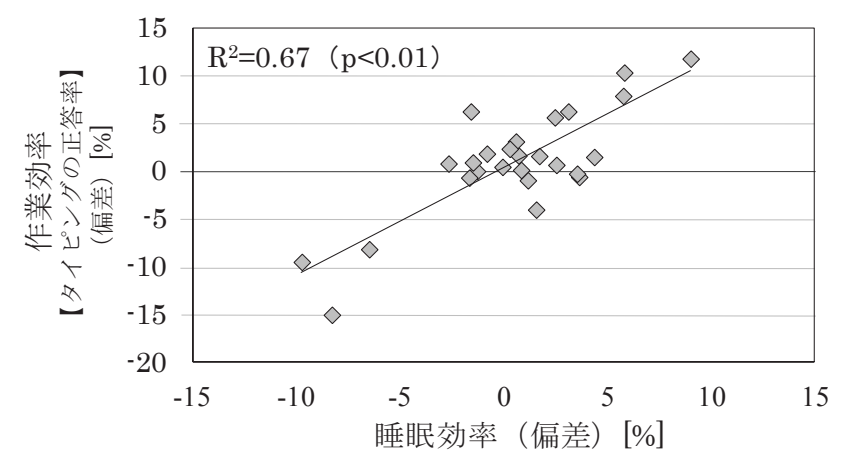

図 13 睡眠効率とタイピングの正答率の関係 $(n=26)$

$\square$ Case. I (SET $\left.* 24.9^{\circ} \mathrm{C}\right) \square$ Case. II (SET $\left.27.4^{\circ} \mathrm{C}\right) \square$ Case. III (SET $\left.* 30.4^{\circ} \mathrm{C}\right)$

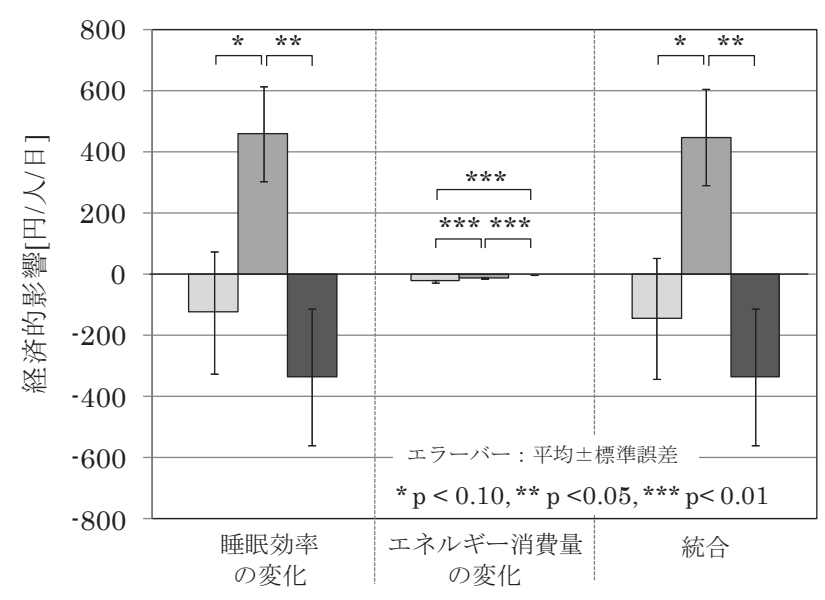

図 14 睡眠効率及びエネルギー消費量の変化による経済的影響 (実験ケース別 $\mathrm{n}=7$ )

7. まとめ

\section{1 結論}

本稿では夏季の温熱環境制御が睡眠と省エネに与える影響の経済 性評価を行うことを目的として被験者実験を実施した。その結果、 以下の 4 点の結論を得た。

1) 平均 SET*が $27.4^{\circ} \mathrm{C}$ であった Case. II において、起床時の睡眠 感が向上し、睡眠効率が最も高くなる傾向が示された。睡眠効率に 関して、Case. II と Case.III（平均 SET*30.4 ${ }^{\circ} \mathrm{C}$ ）の比較では Case. IIIにおいて睡眠効率の低下が確認され（p<0.05）、Case. I （平均 $\left.\mathrm{SET}^{*} 24.9^{\circ} \mathrm{C}\right)$ に関しても同様に低下寸る傾向が見られた $(\mathrm{p}<0.10)$ 。 
2 ）睡眠効率が低い日ほど作業前の眠気を感じている傾向が確認さ れた。また、睡眠効率が高い日ほど、作業中の作業意欲が高く維持 される傾向が示唆された。

3 ）睡眠効率が高い日ほどマインドマップの回答数が多く、タイピ ングの正答率が高い傾向が確認され、単純作業、知識創造作業とも に睡眠の質向上が好影響を与える可能性が示された。睡眠効率 $1 \%$ の低下に伴い、タイピングの正答率が $1.1 \%$ 低下寸ることが確認され た。

4 ）夏季の温熱環境制御が睡眠と省エネー与える経済的影響を実験 ケース別に比較した結果、Case. II において有意に経済的価值が高 いことが示された。

\section{2 今後の課題}

本報では睡眠の質向上がもたら寸経済的影響が省エネによる経済 的影響よりも非常に大きく、就寝中の平均 $\mathrm{SET}$ *が $27.4^{\circ} \mathrm{C}$ であった Case. II において睡眠効率が最も高くなる傾向を示唆した。しかし、 本研究における温熱環境と睡眠の関係や睡眠効率と作業効率の関係 の分析は、大学生を対象とした実験によって得られたものである。 今後、執務者を対象とした睡眠の質と作業効率の調査、温熱環境制 御と睡眠の質の調査や温度感受性に鈍化がみられる老人を対象とし た調查を実施することで、幅広い年代に適応した汎用性のある結果 が得られることを期待する。執務者や老人を対象とした場合には、 生活習慣の蓄積や職種や健康状態等、温熱環境以外に睡眠に影響を 与える要因が数多く存在するため、より綿密な実験の計画及びサン プル数を確保した上での個人属性別の分析が必要と考えられる。

また、本分析において、睡眠の質低下が与える影響を翌日の作業 効率の低下に限定している。しかし、土井 59) らは睡眠の質低下が 様々な身体疾患や精神疾患と関連していることを示している。これ より、睡眠の質向上がもたら寸経済的影響はさらに大きいことが推 察され、健康症状一の影響をも考慮すべきであると考えられる。

さらに、睡眠の質向上の重要性が示唆されたことから、快適な睡 眠環境構築のため、より詳細な温熱環境制御手法の検証が求められ る。本研究で検証を実施した温熱環境制御は、冷房の連続運転にお ける定常的な温熱環境制御に留まっている点が課題として挙げられ るため、今後は冷房の非定常的な運転方式も含めた検証を実施する 必要があると言える。

\section{謝 辞}

本研究は、東京ガス株式会社の委託研究「居住者の意識・生活行 動がエネルギー消費量と健康へ与える影響の経済性評価に関する調 查研究 (研究代表者: 伊香賀俊治)」及び「居住者の意識・生活行動 がエネルギー消費量と健康へ与える影響の評価指標の導出に関寸る 調查研究 (研究代表者: 伊香賀俊治)」として実施したものである。 本研究の遂行にあたり多大な御協力、御助言を頂きました鈴木真貴 子様 (東京ガス株式会社)、松岡由紀子様 (当時東京ガス株式会社)、 浦田麻衣様 (当時慶應義塾大学大学院)、被験者の皆さまに感謝の意 を表す。

尚、本研究は、科学研究費補助金・基盤研究（A）（研究代表者： 伊香賀俊治、課題番号：26249083）を受け実施したものである。
1）厚生労働省健康局：健康づくりのための睡眠指針 2014, p.4-11, 2014.3 [WEB サイト]http://www.mhlw.go.jp/file/04-Houdouhappyou-10904750Kenkoukyoku-Gantaisakukenkouzoushinka/0000042751.pdf (2015.6.10 参照)

2）三島和夫：睡眠と生活習慣病，公衆衛生, Vol. 75, No.10, pp.755-759, 2011.10

3）厚生労働省: 平成 25 年 国民健康・栄養調査結果の概要, 第 2 章 身体状 況、運動及び睡眠に関する状況, p.14, 2013.11 [WEB サイト]

http://www.mhlw.go.jp/file/04-Houdouhappyou-10904750-KenkoukyokuGantaisakukenkouzoushinka/0000068070.pdf (2015.6.10 参照)

4）日本睡眠学会 : 睡眠学, 朝倉書店, pp.140-143, 2009.1

5) K. Tsuzuki, K Okamoto-Mizuno, K Mizuno : Effects of humid heat exposure on sleep, thermoregulation, melatonin, and microclimate, Journal of Thermal Biology, Vol. 29, No. 1, pp.31-36, 2004.1

6) 都築和代 : 温熱環境と睡眠, 日本生気象学会雑誌, Vol. 50, No.4, pp.125-134, 2014.1

7）垣鍔直：住宅における夏期のエアコン利用に関する実態調査，日本建築学 会大会学術講演梗概集, D- II , pp.247-248, 2001.7

8）垣鍔直，川島庸，伊師真理子：夏期における睡眠時の最適な冷房条件，人 間-生活環境系シンポジウム報告集, Vol. 30, pp.229-232, 2006.12

9）垣鍔直：夏期における睡眠時の好夕の冷房条件，日本建築学会大会学術講 演梗概集, D- II , pp.409-410, 2007.7

10）久保博子, 梁瀬度子, 鈴木有以子 ほか 2 名：夏期と冬期における高齢者 の睡眠と寝室・寝床環境に関するアンケート調查，人間-生活環境系シンポ ジウム報告集, Vol. 26, pp.105-108, 2002.12

11）川島庸，垣鍔直:夏期の睡眠時における最適な冷房条件に関する実験的研 究, 人間と生活環境, Vol. 11, No. 1, pp.31-37, 2004.5

12）都築和代, 森郁恵：高齢者の睡眠に及ぼす冷房方法の影響に関する研究, 人間-生活環境系シンポジウム報告集, Vol. 38, pp.45-46, 2014.11

13）糸井川高穂, 羽山広文, 絵内正道 ほか 1 名 : 病室における睡眠時の対流 式冷房に関する実験的研究，日本建築学会環境系論文集，Vol. 78, No. 631, pp1133-1138, 2008.9

14）井上雄二, 安井圭子, 森田健 : 冷房時の気流制御が睡眠の質に与える影響, 人間-生活環境系シンポジウム報告集, Vol. 30,pp.77-80, 2006.12

15）森戸直美，西宮肇，都築和代 : 冷房の気流が睡眠と皮膚温に及ぼす影響 一被験者実験による冷房方法の比較一, 空気調和・衛生工学会論文集,

No. $161,2010.8$

16）経済産業省資源エネルギー庁: 平成 25 年度エネルギーに関する年次報告 （エネルギー白書 2014），第 2 部エネルギー動向, pp.140-149, 2014.6 [WEB サイト] http://www.enecho.meti.go.jp/about/whitepaper/2014pdf/ whitepaper2014pdf_2_1.pdf（2015.6.10 参照）

17）環境省：家庭における節電・ $\mathrm{CO}_{2}$ 削減行動に関する調查（夏期調査）の 結果について, 2013.5 [WEB サイト]

http://www.env.go.jp/press/files/jp/22132.pdf（2015.6.10 参照）

18）玄地裕，井原智彦，宮沢和貴ほか 2 名：居住環境における健康維持増進 に関する研究 その 10 外気温上昇が居住者の睡眠障害に及ぼす影響，日本 建築学会大会学術講演梗概集, D- I, pp.1003-1004, 2009.7

19）井原智彦，日下博幸，原政之ほか 2 名：問題比較型影響評価手法を用い た都市気温上昇に伴う軽度の健康影響推定，日本建築学会環境系論文集， Vol. 76, No. 662, pp459-467, 2011.4

20) D.P.Wyon: The effects of indoor air quality on performance and productivity, Indoor Air 2004, 14(Suppl 7), pp.92-101, 2004.2

21) Olli Seppanen, PE William J. Fisk, PE David Faulkner.: Control of Temperature for Health and Productivity in Offices, ASHRAE Transactions, 2005.8

22) 羽田正沖, 西原直枝, 田辺新一: 知的生産性によるオフィスの温熱環境の 経済的影響評価，日本建築学会大会学術講演梗概集，D- II , pp.455-458, 2006.7

23）多和田友美，伊香賀俊治，村上周三 ほか 2 名：オフィスの温熱環境が作 業効率及び電力消費量に与える総合的な影響, 日本建築学会環境系論文集, Vol. 75, No. 648, pp213-219, 2010.2

24）川口玄，和田一樹，粕谷敦 ほか 5 名：タスク・アンビエント対応膜放射 冷房システムに関する研究，その 5 -知的生産性評価およびエコ効率分析 に基づく経済性・環境性評価-, 日本建築学会大会学術講演梗概集, D- II, pp.1085-1086, 2010.7 
25) V. Godet-Cayre, N. Pelletier-Fleury, M. Le Vaillant et al. : Insomnia and Absenteeism at Work. Who Pays the Cost?, SLEEP, Vol. 29, No. 2, pp.179-184, 2006.2

26) R. Rosekind, K. Gregory, M. Mallis et al. : The Cost of Poor Sleep: Workplace Productivity Loss and Associated Costs, JOURNAL OF OCCUPATIONAL AND ENVIRONMENTAL MEDICINE, Vol. 52, No. 1, pp.91-98, 2010.1

27）内山真：睡眠障害の社会生活に及ぼす影響と経済損失，日本精神科病院 協議会雑誌, Vol.31, No. 11, pp.1163-1169, 2012.11

28）厚生労働省：平成 26 年度版労働経済の分析, 第 1 章 労働経済の推移と 特徴, p.35-41, 2014.9 [WEB サイト]

http://www.mhlw.go.jp/wp/hakusyo/roudou/14/dl/14-1-1_02.pdf (2015.10.26 参照)

29) AH. Goldsmith, JR. Veum, W. Darity : Working hard for the money? Efficiency wages and worker effort, JOURNAL OF ECONOMIC PSYCHOLOGY, Vol. 21, No. 4, pp.351-385, 2000.10

30）金子隆昌, 村上周三, 伊藤一秀 ほか 1 名 : 現地実測による温熱・空気環 境の質が学習効率に及ぼす影響の検討一学習環境におけるプロダクティビ ティ向上に関する研究，その 1 -, 日本建築学会環境系論文集, No. 606, pp43-50, 2006.8

31）金子隆昌，村上周三，伊藤一秀 ほか 3 名：実験室実験による温熱・空気 環境の質が学習効率に及ぼす影響の検討一学習環境におけるプロダクティ ビティ向上に関する研究，その 2-,日本建築学会環境系論文集，No. 611, pp45-52, 2007.1

32）亀田健一, 村上周三, 伊藤一秀: 室内環境質が学習意欲ならびに学習効率 に与える影響一学習環境におけるプロダクティビティ向上に関する研究, その 3-, 日本建築学会環境系論文集, Vol. 74, No. 642, pp943-949, 2009.8 33）羽田正沖, 西原直枝, 田辺新一: 温熱環境と換気量が知的生産性に与える 影響に関する被験者実験，日本建築学会環境系論文集，Vol. 74, No. 638, pp.507-515, 2009.4

34）羽田正沖，西原直枝，川口玄ほか 1 名：夏季に室温を高めに設定した才 フィスにおける知的生産性一採涼手法の導入による温熱満足度の向上と 作業効率および疲労への影響一, 日本建築学会環境系論文集, Vol. 74, No. 646, pp.1329-1337, 2009.12

35）西川雅弥, 西原直枝, 田辺新一: 中程度の高温環境下の長時間作業が作業 効率と疲労に与える影響に関する被験者実験, 日本建築学会環境系論文 集, Vol. 74, No. 638, pp.525-530, 2009.4

36）高橋祐樹，加藤信介，小林敏孝 ほか 7 名: サーカディアンリズムを考慮 したオフィスの温熱環境制御が執務者の深部体温とその他生理 - 心理・作 業効率に与える影響, 日本建築学会環境系論文集, Vol. 76, No. 662, pp.335-343, 2011.4

37）高橋祐樹, 加藤信介, 小林敏孝 ほか 7 名: 環境変化に敏感な性格傾向を 持つ執務者の日中の活動・夜間の睡眠についての検討-サーカディアンリズ ムを考慮したオフィスの温熱環境制御が執務者の深部体温とその他生理・ 心理・作業効率に与える影響 その 2-, 日本建築学会環境系論文集, Vol. 79, No. 695 , pp.11-17, 2014.1

38) 日本肥満学会: 肥満研究 肥満症診断基準 2011, 日本肥満学会誌, Vol. 17, 2011.10

39) 近藤英明, 神林崇, 清水徹男: 睡眠と飲酒（特集 睡眠と生活習慣病）, 成 人病と生活習慣病, Vol. 40, No. 4, pp.386-389, 2010.4

40) DIMSDRIVE : 『エアコン』に関するアンケート [WEB サイト] http://www.dims.ne.jp/timelyresearch/2007/070522/ (2015.6.10 参照)

41）経済産業省資源エネルギー庁 : 家庭の省エネ徹底ガイド, p.6, 2013.3 [WEB サイト] http://www.enecho.meti.go.jp/about/pamphlet/pdf/katei_ tettei.pdf (2015.6.10 参照)

42）日本睡眠学会 : 初心者のための睡眠の基礎と臨床, p.1-8, 1999.6 [WEB サイト] http://jssr.jp/kiso/syoshin/syoshin.pdf（2015.6.10 参照）

43) 吉竹博: 改訂産業疲労-自覚症状からのアプローチ-, 労働科学研究所出版 部, 1973.1

44）山本由華吏，田中秀樹，高瀬美紀 ほか 3 名：中高年・高齢者を対象とし た OSA 睡眠調査票 (MA 版) の開発と標準化, 脳と精神の医学 10, p.401-409, 1999.12

45）久保博子：クーラー使用時の寝室温熱環境が睡眠に及ぼす影響について, 第 19 回睡眠環境シンポジウム, 日本睡眠学会 調査報告, 2004.7

46）健康維持増進住宅研究委員会 : 健康に暮らすための住まいと住まい方エ ビデンス集，技報堂出版, 2013.6
47）大林賢史，佐伯圭吾，刀根庸浩：日常生活における夜間光曝露量と睡眠障 害の関連，住環境に関する大規模疫学調査（平城京スタディ）, 日本建築学 会大会学術講演梗概集, D- I , pp.397-398, 2014.9

48) 深井一夫, 伊藤宏, 後藤滋 ほか 2 名：標準新有効温度 $\left(\mathrm{SET}^{*}\right)$ と日本 人の温熱感覚に関する実験的研究 第 2 報-冬期および夏季における温熱感 覚の比較, 空気調和 · 衛生工学会学術講演論文集 Vol.51, pp.139-147, 1993.2

49）深井一夫：標準新有効温度 $\left(\mathrm{SET}^{*}\right)$ における放射，湿度，気流，着衣の 影響の温度換算，日本建築学会計画系論文集，第465号, pp.19-26, 1994.11 50）中村泰人, 横山真太郎, 都築和代 ほか 4 名：日常生活で生じる気候適応 を把握するための居住環境温度の多地域同時計測法，人間と生活環境， Vol.15, No.1, pp.5-14, 2008.5

51）宮本征一：オフィス空間におけるスーツ着用時の温熱的快適域に関する 研究 その 2 夏季の中程度高温環境下における温冷感に男女の差異につ いて, 日本建築学会環境系論文集, 第 73 巻, 第 628 号, pp.715-720, 2008.6 52) 安岡絢子, 久保博子, 磯田憲生 ほか 1 名：住空間における生理心理反応 からみた温熱的快適範囲の季節差に関する研究, 日本建築学会環境系論文 集, 第 76 巻, 第 663 号, pp.479-484, 2011.5

53）空気調和・衛生工学会 : 快適な温熱環境のメカニズム, p.113-119, 2006.6 54) 羽原宏美, 三浦尚志, 細井昭憲 ほか 2 名:夏期および中間期における通 風冷房行為の再現による $\mathrm{RC}$ 集合住宅の室内温熱環境および冷房消費電力 量に関する研究 住宅のための省エネルギー手法の実験的研究に関する研 究 その 2, 日本建築学会環境系論文集, Vol. 73, No. 633, pp.1321-1329, 2008.11

55）日本建築学会編集 : 建築物の遮音性能基準と設計指針 第二版, 1997.12

56) 厚生労働省：平成 26 年度版労働経済の分析, 第 1 章 労働経済の推移と 特徵, p.27-36, 2014.9 [WEB サイト]

http://www.mhlw.go.jp/wp/hakusyo/roudou/14/dl/14-1-1.pdf (2015.6.10 参照)

57）日経 BP 社：1日のうち、仕事でパソコンに接する時間, 2007.7 [WEB サイト] http://pc.nikkeibp.co.jp/article/NPC/20070706/276946/ (2015.7.9 参照)

$58 ）$ 公益社団法人 全国過程電気製品公正取引協議会 :「電力料金の目安単価」 の改訂に関する件，2014.4 [WEB サイト] http://www.eftc.or.jp/qa/qa_pdf.pdf（2015.6.10 参照）

59）土井由利子：日本における睡眠障害の頻度と健康影響, 保健医療科学, Vol. 61, No. 1, pp.3-10, 2012.2

60）東京ガス都市生活研究所 都市生活レポート：現代人の睡眠事情 2015 ～寝室の現状と睡眠実態〜, p.14, 2015.9 [WEB サイト] http://www.toshiken.com/report/life27.html（2016.2.17 参照） 61) 三品昌美 : 分子脳科学 分子から脳機能と心に迫る, 化学同人, 2015.4

注

注 1）省エネ・創エネ・蓄エネ設備を導入した住宅。

注 2) BMI は Body Mass Index の略称であり、[BMI=体重 $\left.[\mathrm{kg}] \div(\text { 身長 }[\mathrm{m}])^{2}\right]$ により算出される。1 8.5 未満が「低体重」、18.5 以上 25.0 未満が「標準」、 25.0 以上が「肥満」に分類される

注 3）規則正しい生活を送る被験者を選定するため、夜勤を行っていない点に 関しても選定条件とした。

注 4）被験者は実験開始直前の 1 2 週間の間、自宅にて睡眠状態の測定を行 った。これにより、普段の睡眠状態の把握を行った。被験者毎の自宅にお ける平均総就床時間を図 15 に示寸。総就床時間の平均が 6 時間未満の被験 者が 4 名、 6 時間以上の被験者が 4 名であった。個人毎の標準偏差は 1 時 間程と、極端な総就床時間の変動は確認されなかった。

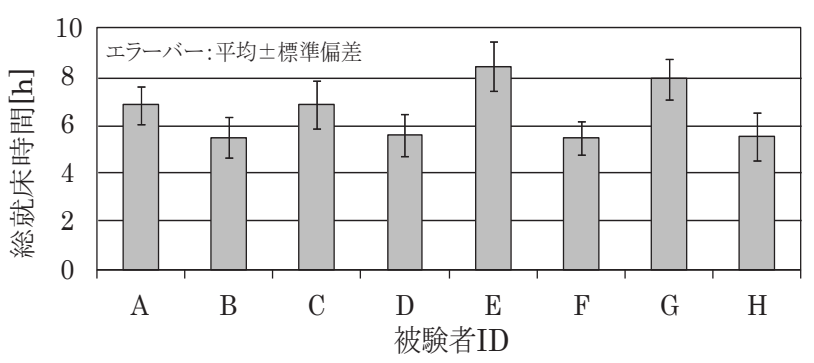

図 15 普段の総就床時間の平均値（被験者別） 
注 5）現代人の寝具に関して東京ガス都市生活研究所が実施した調查 60)にお いて 10〜20 代の男性の 37.0\%が布団を使用していることが示されている。 本実験の被験者に関しても 2013 年実験の被験者は 3 名が布団、 5 名がベッ ドを使用しており、2014 年実験の被験者は 4 名が布団、4 名がベッドを使 用していたことから、実験時の寝具条件が若者の実生活から大きく乘離し ていないことを確認した。また、自宅と異なる寝具を用いることによる睡 眠への影響を極力小さくするため、自宅で使用している枕を使用した。

注 6）普段の総就床時間と異なる条件とすることで、睡眠効率に影響を与える 可能性があるため、自宅と実験を行った睡眠空間での睡眠効率を被験者毎 に比較した（図 16）。その結果、普段の生活との総就床時間の差が大きい 被験者であっても、両者に有意な差は認められなかった。

（ ）内は有効サンプル数【【」内は自宅での総就床時間の平均值

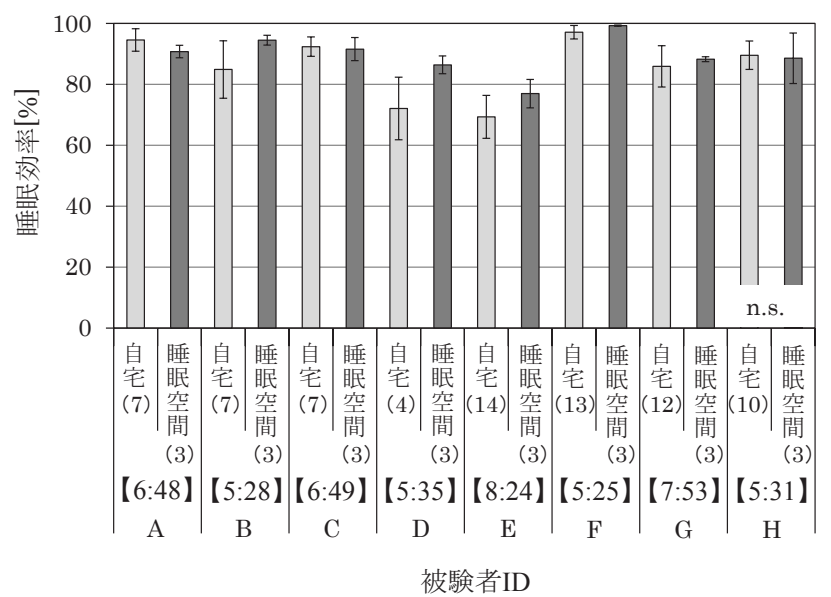

図 16 自宅および睡眠空間の睡眠効率（平均値士標準偏差）

注 7）実験を実施した全日程における、自律神経の活性度割合を図 17,18 に 示す。自律神経の活性度割合とは交感神経（緊張状態を反映する指標）と 副交感神経（リラックス状態を反映する指標）の活動の優劣を示す指標で ある。結果、全日程において、覚醒時に交感神経の活動が優位となり、睡 眠時に副交感神経の活動が優位となる自律神経の適切な日内変動リズム ${ }^{61)}$ が確認された。

$\square$ 副交感神経活性度 $\square$ 交感神経活性度

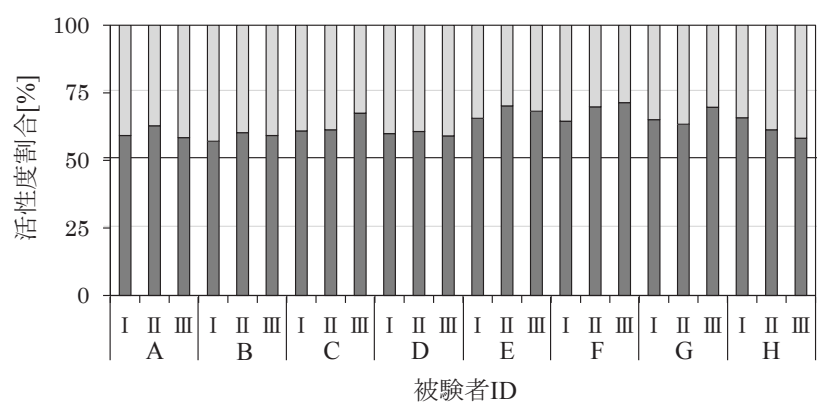

図 17 覚醒時の自律神経活性度割合（被験者別）

$\square$ 副交感神経活性度 $\square$ 交感神経活性度

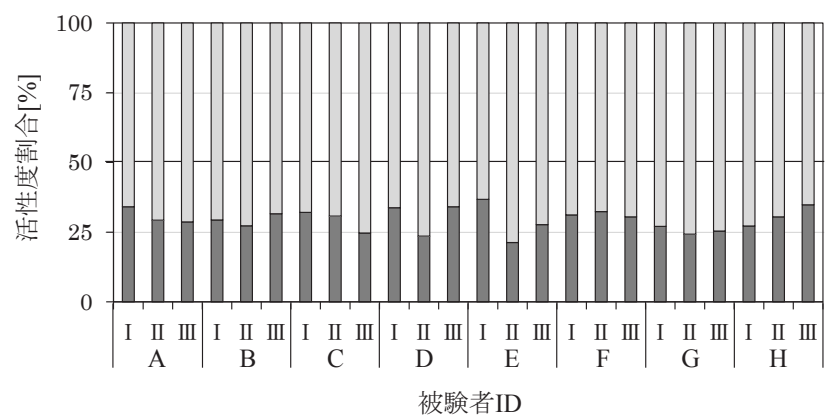

図 18 睡眠時の自律神経活性度割合（被験者別）
注 8）睡眠の質を評価する指標としては「睡眠効率」の他に、「入眠潜時（寝付 くまでの時間）」や「中途覚醒時間」が挙げられる。そこで、翌日の作業効率 と最も関連が強い指標を検証するため、相関分析を実施した（表 10）。睡 眠効率が最も翌日の作業効率との関連が強いことが示唆された。

\section{表 10 睡眠評価指標と作業効率の相関分析}

${ }^{*} \mathrm{p}<0.10,{ }^{* *} \mathrm{p}<0.05,{ }^{* * *} \mathrm{p}<0.01$

\begin{tabular}{l|c|c|c} 
& 睡眠効率 & 入眠潜時 & 中途覚醒時間 \\
\hline タイピングの正答率 & $0.82 * * *$ & -0.24 & $-0.53 * * *$ \\
\hline マインドマップの回答数 & $0.50 * *$ & 0.12 & $-0.38 *$ \\
\hline
\end{tabular}

注 9）睡眠感を評価する心理尺度。

注 10）普段の睡眠状態の把握を目的として実験前 1 ～週間に実施した自宅 での睡眠状態の測定結果を用いて 2013 年実験と 2014 年実験の被験者の 睡眠効率を比較した（図 19）。その結果、2013 年実験に参加した被験者の 平均睡眠効率は $86.7 \pm 10.1 \% 、 2014$ 年実験の被験者は平均 $86.3 \pm 8.5 \%$ と

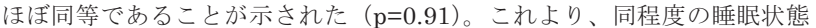
の被験者を対象とした実験であることが確認された。

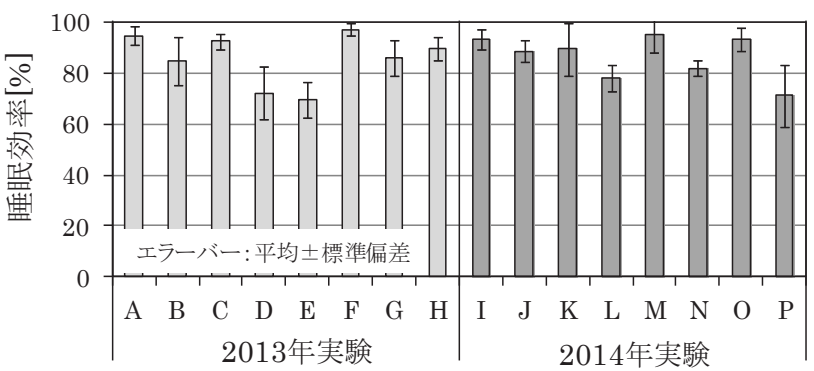

図 19 普段の睡眠効率の平均値（被験者別）

注 11）1つのキーワードから連想される言葉を書き出す作業。

注 12）本実験は 1 住戸内の複数の居室を睡眠空間とし、睡眠の測定を実施し た。1階居室と寝室として使用される 2 階居室の差を極力小さくするため、 光環境・音環境を統一するよう努めた。測定結果より、居室間の光環境及 び音環境に有意な差が認められないことを確認した（表 11）。

\section{表 11 居室別の光環境・音環境}

\begin{tabular}{c|c|c|c|c}
\multicolumn{2}{|c|}{} & 居室 1 & 居室 2 & 居室 3 \\
\hline \multirow{2}{*}{ 照度[lx] } & 就寝前 & $137 \pm 33$ & $122 \pm 15$ & $146 \pm 21$ \\
\cline { 2 - 5 } & 起床後 & $220 \pm 56$ & $241 \pm 79$ & $258 \pm 34$ \\
\hline \multirow{2}{*}{ 騒音[dB] } & 就寝前 & $39.6 \pm 1.8$ & $37.8 \pm 2.5$ & $37.4 \pm 1.8$ \\
\cline { 2 - 5 } & 起床後 & $39.4 \pm 1.8$ & $36.8 \pm 2.8$ & $38.4 \pm 2.8$ \\
\hline
\end{tabular}

注 13）標準状態における着衣量 $(0.6 \mathrm{clo})$ 、代謝量 $\left(52 \mathrm{~W} / \mathrm{m}^{2}\right)$ と睡眠状態に おける着衣量 (1.3clo)、代謝量 $\left(40 \mathrm{~W} / \mathrm{m}^{2}\right)$ を用いた場合の就寝中平均 $\mathrm{SET}^{*} *$ を表 12 亿示す。その結果、睡眠状態の SET*は睡眠時の代謝量が低いこと が要因となり、日常生活で体感する温度とずれが生じることが確認された。 これより、本研究では各ケースの室内温熱環境を標準状態の SET*を用い て示した。

表 12 就寝中平均 $\mathrm{SET}^{*}$ (平均值士標準偏差)

\begin{tabular}{c|c|c|c} 
& Case. I & Case. II & Case. III \\
\hline 標準状態の SET* $\left[{ }^{\circ} \mathrm{C}\right]$ & $24.9 \pm 0.9$ & $27.4 \pm 1.4$ & $30.4 \pm 1.4$ \\
\hline 睡眠状態の $\mathrm{SET}^{*}\left[{ }^{\circ} \mathrm{C}\right]$ & $23.5 \pm 0.9$ & $25.7 \pm 1.1$ & $28.1 \pm 1.1$ \\
\hline
\end{tabular}

注 14) 枕元の高さ $(0.1 \mathrm{~m})$ での測定結果の平均值。

注 15）分析対象とする 7 名に関して、就寝前の疲労感をケース別に示す（図 20)。疲労感は身体的、精神的、神経的の 3 つに分類され、各 10 項目の症 状のうち、当てはまった症状の数を割合として示す。その結果、ケース間 に有意な差は認められず、就寝前の疲労感が実験期間中、同等であること が示唆された。 
$\square$ Case. I (SET*24.9 $\left.{ }^{\circ} \mathrm{C}\right) \square$ Case. II $\left(\mathrm{SET}^{*} 27.4^{\circ} \mathrm{C}\right) \square$ Case. III (SET*30.4 $\left.{ }^{\circ} \mathrm{C}\right)$

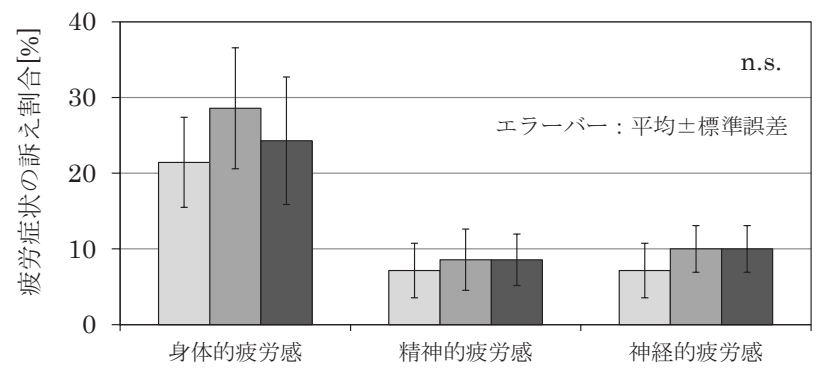

図 20 実験ケース別の就寝前の疲労感 $(n=7)$

注 16）睡眠感は 5 つの睡眠因子に分類される。（因子 I :起床時眠気、因子 II : 入眠と睡眠維持、因子III: 夢み、因子IV:疲労回復、因子 $\mathrm{V}$ :睡眠時間)

注 17）被験者毎の実験期間中の睡眠効率の平均值を図 21 に示す。最も平均 睡眠効率が高い被験者 $\mathrm{F}$ と睡眠効率の低い被験者 $\mathrm{E}$ の間に $22 \%$ の差を確認 し、個人差を極力除外する必要があると判断した。

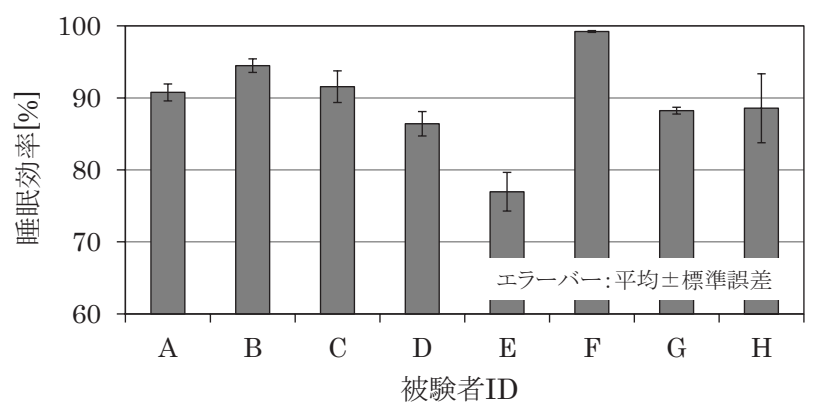

図 21 実験期間中の睡眠効率の平均值（被験者別）
注 18）実験ケース別の睡眠効率を図 22 に示す。個人差の影響が大きく、有 意な差は認められないが、Case. IIにおいて睡眠効率が高い傾向が示された。

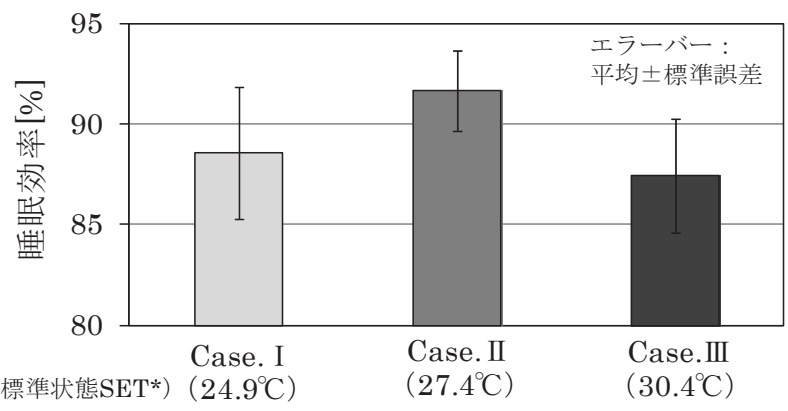

図 22 実験ケース別の睡眠効率の平均值 $(n=7)$

注 19）睡眠効率とアンケート調査で得られた主観作業効率との関係を図 23 に示す。その結果、睡眠効率が高い日ほど主観的な作業効率が高い傾向が 示された $\left(\mathrm{R}^{2}=0.32, \mathrm{p}<0.01\right)$ 。

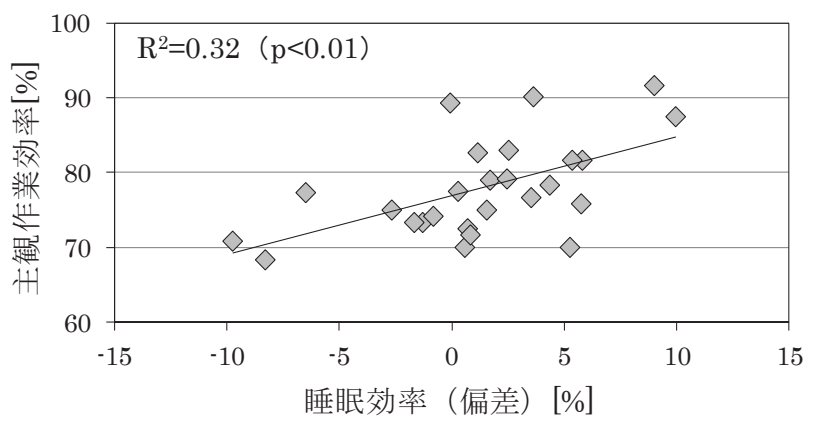

図 23 睡眠効率と主観作業効率の関係 $(n=26)$ 


\title{
ECONOMIC EVALUATION ON THE EFFECT OF THERMAL ENVIRONMENTAL CONTROL IN SUMMER ON SLEEP AND WORK EFFICIENCY
}

\author{
Eri HONDA*, Toshiharu IKAGA**, Noboru OHIRA***, \\ Keiji OKAJIMA**** and Wataru UMISHIO ***** \\ * Grad. Stud., Graduate School of Science and Technology, Keio Univ. \\ ** Prof., Faculty of Science and Technology, Keio Univ., Dr.Eng. \\ *** Manager, Residential Sales Marketing Department, Tokyo Gas Co., Dr.Eng \\ **** Manager, Residential Sales Marketing Department, Tokyo Gas Co. \\ ***** Kajima Corporation, MEng. \\ (Grad. Stud., Graduate School of Science and Technology, Keio Univ.)
}

Decline in the quality of sleep increases the morbidity and risk of lifestyle diseases. In addition, daytime sleepiness causes traffic accidents and decreased work efficiency. According to a survey conducted by the Japanese Ministry of Health, Labour and Welfare, $20 \%$ of people experience sleep problems, and decline in sleep quality in particular is serious. One factor that has been linked to decline in sleep quality is high heat and humidity in summer.

Against this background, some studies have examined the effects of thermal environment control on sleep. Appropriate use of air conditioning has been shown to improve sleep quality; however, maintaining a good indoor thermal environment using air conditioning increases energy consumption. Given the present state of climate change, the reduction of energy consumption in the Japanese residential sector is a pressing issue. However, an excessive reduction in air conditioning use for the purpose of saving energy could create a poor sleep environment. The effects of thermal environment control using air conditioning on sleep quality and energy consumption have been independently investigated in several previous studies.

In this research, we elucidate the impact of thermal environment control on both sleep and energy consumption during the summer. The effect of thermal environment control on sleep and energy saving was unified as a monetary value. Increase in energy consumption can be estimated as an increase in air conditioning costs. Conversely, because reduced sleep efficiency translates to reduced working efficiency, improved sleep efficiency was converted into monetary value as a reduction in wages.

Eight healthy male university students participated in this study. The study was performed in a two-story maisonette room in an apartment building with high environmental performance. Experiments were conducted in August 2013 and 2014. In the 2013 experiments, we examined the effect of thermal environment control on sleep and energy consumption. Three thermal environmental control scenarios were used: an air conditioner set at continuous operation at $26.0^{\circ} \mathrm{C}$ (Case I); an air conditioner set at continuous operation at $28.0{ }^{\circ} \mathrm{C}$ (Case II); and natural draft only (Case III). The increase in air conditioner temperature setting from 26.0 to $28.0^{\circ} \mathrm{C}$ used in this study resulted in a $0.03 \mathrm{kWh} /$ day $/ \mathrm{m}^{2}$ reduction in 8-h energy consumption (Fig. 6). Sleep efficiency was significantly higher for Case II (average SET* during sleep, $27.4{ }^{\circ} \mathrm{C}$ ) (Fig. 8). Low SET* caused by excessive air conditioner use and high SET* caused by not using an air conditioner adversely affected sleep efficiency. The relationship between sleep efficiency and work efficiency was verified in the experiments conducted in August 2014, confirming that the economic impact of decreased sleep efficiency could be converted to a monetary value. Working efficiency decreased by $1.1 \%$ per $1 \%$ decrease in sleep efficiency ( $<<0.01$ ) (Fig. 13). The combined economic impact of energy saving and sleep quality was calculated. The economic impact of improved sleep quality was much greater than that of energy saving, and the economic value of Case II (average SET* during sleep, $27.4^{\circ} \mathrm{C}$ ) was the highest (Fig. 14).

This study found that sleep quality influences work efficiency, demonstrating the importance of improving sleep. To create a comfortable sleeping environment, further verification of thermal environment control in more detail is necessary. 